\title{
BOEKBESPREKINGEN
}

\section{J.H.H.M. Dorscheidt e.a. (red.), Rechtspraak Gezondheidsrecht*}

\author{
Prof. mr. J.C.J. Dute
}

De ontwikkeling van het gezondheidsrecht wordt in belangrijke mate bepaald door wetgeving. Dat neemt niet weg dat ook de rechtspraak een niet te verwaarlozen rol speelt. Voor veel rechtsgebieden is de belangrijkste jurisprudentie voor onderwijsdoeleinden gebundeld, voor het gezondheidsrecht ontbrak tot nog toe een dergelijk overzicht. In deze leemte voorziet deze uitgave.

De bundel omvat ruim tachtig gezondheidsrechtelijke uitspraken, geordend naar de deelgebieden tuchtrecht, civiel recht, bestuursrecht, strafrecht, BOPZ-recht, geneesmiddelenrecht, Europees recht en 'overige'. De weergave van de uitspraken volgt een vast stramien: eerst worden de partijen aangeduid, dan volgt een samenvatting van de feiten, vervolgens wordt (kort) het verloop van de procedure geschetst. Daarna worden (in cursief) de kernoverwegingen weergegeven, gevolgd door een commentaar. Ten slotte wordt verwezen naar literatuur over de uitspraak.

In de inleiding valt te lezen dat 'de redactie bij de selectie van uitspraken zich primair heeft laten leiden door de onderwijsgeoriënteerde functie van de bundel en het doel van snelle raadpleging ervan in de zorg- en rechtspraktijk'. Ik denk dat voor de zorg- en rechtspraktijk de bundel niet erg bruikbaar is. Daar zijn vaak specifieke vragen aan de orde, waardoor de selectie van uitspraken al gauw te

* J.H.H.M. Dorscheidt, T.A.M. van den Ende, M.J.J. de Ridder \& J.H. Hubben (red.), Rechtspraak Gezondheidsrecht, Den Haag: Sdu Uitgevers 2016 (ISBN 978-90-12-39801-5)

** Jos Dute is lid van het College voor de Rechten van de Mens, hoogleraar gezondheidsrecht aan de Faculteit der Rechtsgeleerdheid van de Radboud Universiteit en redacteur van dit tijdschrift. beperkt zal zijn. De bundel had beter geheel op het onderwijs gericht kunnen zijn.

In de inleiding wordt verder opgemerkt dat de rechtspraakkeuze onvermijdelijk 'bestaande voorkeuren van de redactie weerspiegelt' en 'een zeker arbitrair karakter niet geheel kan worden ontzegd'. Dat moge zo zijn, maar op onderdelen had de redactie, zeker met het oog op de onderwijsfunctie, beter andere keuzes kunnen maken.

Zo treffen we in het onderdeel tuchtrecht bekende evergreens aan, zoals de CTG-uitspraak over de verhouding opleider en aio's en die over de verantwoordelijkheden van de hoofdbehandelaar en de regievoering. Ook de CTG-uitspraak uit 2011 waarin de tuchtrechter omging op het punt van de ontvankelijkheid van een klacht over een arts met een bestuurlijke functie, ontbreekt niet. Maar waarom is ook een CTG-uitspraak uit 2009 over het zonder toestemming operatief verwijderen van de huig in de bundel opgenomen? Idem waar het gaat om een CTG-uitspraak uit 2010 over een experimentele behandeling buiten het kader van een medisch-wetenschappelijke studie. Deze uitspraken hebben mijns inziens weinig nieuws gebracht.

De selectie van civielrechtelijke uitspraken is adequaat, al is mij niet duidelijk waarom ook is gekozen voor de recente uitspraak van Rechtbank Rotterdam over de aansprakelijkheid van ziekenhuizen voor de hersteloperaties als gevolg van de gebrekkige PIPborstimplantaten. Deze problematiek is nog onvoldoende uitgekristalliseerd. Ook de keuzes in de onderdelen bestuursrecht en strafrecht kan ik onderschrijven. Daarentegen hadden wat mij betreft de onderdelen BOPZ-recht (zeven uitspraken) en geneesmiddelenrecht (negen uitspraken) wel kun- 
nen worden gemist. Deze gebieden zijn te specialistisch voor een bundel als deze. Verder is de selectie Europees recht erg willekeurig en vier (van de zeven) uitspraken gaan wederom over geneesmiddelen. Zo ontstaat geen goed beeld van de Europese rechtspraak, in het bijzonder niet van de rechtspraak van het Europese Hof voor de Rechten van de Mens. Het onderdeel 'overige' omvat twee uitspraken, één van een Regionale Toetsingscommissie Euthanasie en één van het Scheidsgerecht Gezondheidszorg. Wellicht nuttig als eye opener, maar voor het overige ontgaat het mij waarom deze uitspraken zijn opgenomen.

Hoewel de keuze van de uitspraken op onderdelen voor discussie vatbaar is, is het goed dat er voor het gezondheidsrecht nu eindelijk een rechtspraakbundel is. De weergave van de uitspraken is overzichtelijk, met een goede balans tussen samenvatting en letterlijk aangehaalde - rechtsoverwegingen, de commentaren zijn to-the-point en instructief, en de bundel is goed toegankelijk door de verschillende registers. Zeker in het onderwijs zal deze uitgave zijn weg beslist vinden. 